\title{
Democracy and Transparency
}

\author{
James R. Hollyer Yale University \\ B. Peter Rosendorff New York University \\ James Raymond Vreeland Georgetown University
}

\begin{abstract}
Are democracies more transparent than other types of political regimes? Many people believe that the presence of elections alone is not sufficient for a country to be considered democratic and that transparency must be included as part of the definition of political regime. We agree that contestability of elections and transparency of policymaking are analytically distinct concepts. Adopting minimalist approaches to democracy and transparency, we ask a basic question: do electoral politics provide incentives for governments to disseminate data? We thus investigate theoretically the relationship between regime type and the willingness of policy makers to provide credible announcements on policy-relevant variables. And we demonstrate empirically that the availability (or absence) of policy-relevant data is correlated with regime type, even after controlling for GDP per capita, IMF participation, country fixed-effects, and time trends ${ }^{1}$. Democracies are indeed more transparent.
\end{abstract}

1 re democracies more transparent than other political regimes? The answer to this question is often assumed to be "yes." Indeed, in the minds of many, transparency has become synonymous with democracy. As Shapiro suggests, "democratic leaders can never be entirely free from a commitment to truth-telling" $(2003,200)$.

The logic underlying this argument, however, can be called into question. Minimalist definitions (e.g., Przeworski et al. 2000; Schumpeter 1942) treat democracy as reflecting electoral competition, which need not imply government transparency. Indeed, their greater vulnerability to public disapproval may make democratic officials more inclined to obfuscate or withhold information than their autocratic counterparts-who need worry less about public perceptions. For instance, Mani and Mukand (2007) argue that democratic governments, more so than authoritarian ones, have incentives to allocate resources to public goods that are highly visible, ignoring issues that are less visible. Kono (2006) argues that democratic governments actively promote the transparency of trade policy areas where they can take actions that please voters, while they obscure policy areas where government action goes against the will of the majority. Rejali (2007) makes a related case with respect to human rights, arguing that political regime influences the type of torture techniques a government may employ but not whether they will engage in torture, as democratic governments opt for "clean" techniques that leave no visible trace ex post. All of these studies, which are supported by empirical evidence, argue that the policymaking of democratic governments is shaped by transparency and, importantly, democratic governments have incentives to obfuscate evidence.

We thus ask a basic question: do electoral politics in and of themselves provide any incentives for governments to disseminate data? Or, instead, do electoral politics intrinsically generate incentives for governments to hide information? After all, many people believe that the presence of elections alone is not sufficient for a country to be considered a democracy and that transparency must be included as part of the definition of political regime. ${ }^{2}$

In this study, we build a theoretical argument as to the conditions under which governments prefer to make information available to their polities about their policy choices. This information allows voters to make informed decisions-particularly economic decisions-raising voter welfare. In electoral systems

\footnotetext{
${ }^{1}$ Data and supporting materials to replicate the statistical results in this study can be found at https://files.nyu.edu/bpr1/public/ and
} http://journals.cambridge.org/JOP.

${ }^{2}$ This is the view of the advocacy organization, Freedom House (see http://www.freedomhouse.org), and it is related to the work of Dahl (1971).

The Journal of Politics, Vol. 73, No. 4, October 2011, Pp. 1191-1205

doi:10.1017/S0022381611000880

(C) Southern Political Science Association, 2011

ISSN 0022-3816 
where the survival of the government depends more strongly on voter welfare-i.e., in democracies-the ruling elite will be more willing to disclose policy information. By so doing, it helps to promote the welfare of voters and thus ensure its continued survival in office. ${ }^{3}$

To test this theoretical claim, we construct a new index of transparency-here defined as a government's willingness to disseminate policy-relevant data. To construct this index, we rely on what is often regarded as a nuisance in empirical studies: missing data. We examine all 172 variables related to Economic Policy and Debt available from the World Bank's World Development Indicators (WDI) annual data series and code the presence or absence of data. ${ }^{4}$ Our measure of transparency is the fraction of these variables reported in a given country-year. We thus produce a continuous transparency index stretching from 1960 to 2008 for up to 181 countries that relates closely to our theoretical interest in data dissemination.

Both transparency and democracy are complicated, multidimensional concepts. There may be more to democracy than the ballot box and more to transparency than the dissemination of data. By narrowing the focus to these particular attributes of democracy and transparency, we can generate clear theoretical predications amenable to empirical investigation. Moreover, our narrow definitions may act as proxies for broader concepts. The presence/absence of elections may proxy for the "representativeness" of the polity; and data dissemination may proxy for the "availability" of information. ${ }^{5}$ We therefore also

\footnotetext{
${ }^{3}$ Our claims in this article are similar to those advanced by Bueno de Mesquita et al. (2003), who argue that regimes with larger "winning coalitions"-i.e., democracies-are more likely to disclose information than regimes with small winning coalitions. To test this argument, they examine governments' reporting of tax revenues and national income. The selectorate model used by Bueno de Mesquita et al. is a complete information game however, and it is difficult to discern the meaning or purpose of transparency in such a model. Unlike Bueno de Mesquita et al., we explicitly model government transparency in a model of incomplete information. (We would like to thank an anonymous reviewer for bringing this comparison to our attention.) We also construct a more nuanced (continuous) measure of transparency based on the missing values from a broad array of variables drawn from the WDI, rather than relying on binary indicators based on a subset of variables. In this sense, our measurement is also an advance over earlier work by Rosendorff and Vreeland (2006).

${ }^{4}$ We code only variables that are reported by at least one country in every year the WDI is reported. We defer to the World Bank's classification of variables as related to Economic Policy and Debt.

${ }^{5}$ For a thorough treatment of this issue, see Przeworski, Stokes, and Manin (1999).
}

speak to the more general relationship between democracy and transparency.

In what follows, after defining the key terms, we present the argument about why democracies should be more transparent than nondemocracies. This hypothesis is then subjected to several empirical tests, controlling for factors such as the capacity to collect data, the level of development, participation in international surveillance programs, country fixed effects, and time dependence. We conclude with a discussion of the methodological implications from our findings for studies of democracies.

\section{Defining Democracy and Transparency}

The study of transparency and its relationship with democracy is fraught with difficulties, one of which is the possibility of tautology. While we are concerned in our study with the transparency of policymaking and, more specifically, with the dissemination of information, the broad concept of transparency also applies to a full range factors that affect information flow within a society. Transparency thus pertains to questions of who rules, how governments might be replaced, and, indeed, how elections are contested in countries that fill key offices through an electoral process. In other words, transparency may pertain to the very question of whether one can call a political regime "democratic."

Such concerns partly drove the dissatisfaction of scholars like Dahl (1971) with a minimalist conception of democracy, such as that proposed by Schumpeter (1942), who defines political regimes by the method of filling political offices, whether through electoral or other means. In Dahl's view, in order for there to be contestation at the ballot box, voters must make informed decisions, which, in turn, requires freedoms of speech, assembly, and press, among others. In other words, Dahl's conception of democracy requires, by definition, the free flow of information-ortransparency.

Democracy and transparency have thus been conceived as having multiple dimensions and some of these dimensions overlap explicitly. This conceptualization introduces an analytical tension into the inquiries of the relationship between democracy and transparency. Consider the work of scholars like Mani and Mukand (2007), Kono (2006), and Rejali (2007) who have proposed that the decisions of democratic governments are shaped in part by the 
degree of obfuscation they enjoy, and, moreover, that democratic governments may even have incentives to promote opacity with respect to their policymaking decisions. The analytical tension is obvious: if democracy is, by definition, transparent, then the degree to which governments enjoy and promote obfuscation is simply a measure of their nondemocraticness. Conceptions that define democracies as transparent regimes, thus, in a sense, preclude interesting and important questions about the relationship between political regime and the flow of information.

We acknowledge the complexity and multidimensionality of the concepts of democracy and transparency. Yet, we find the question of whether electoral politics provide governments incentives towards transparency or obfuscation too important to ignore or to decide by fiat. The current controversy between the U.S. State Department and Wikileaks, as well as the studies of Mani and Mukand, Kono, and Rejali make clear that democratic governments strategize according to, rely upon, and even promote the degree of obfuscation they enjoy in policymaking. Kono's (2006) work shows that political regime can cut both ways: he argues, on the one hand, that democracy does not improve citizens' knowledge of government policies, but he presents quantitative evidence that political regime does shape policy, precisely because it is democracy-induced transparency that causes governments to adopt complex and opaque trade policies. Using qualitative evidence, Rejali (2007) corroborates a similar argument about human rights policy. Because democracies are more transparent, governments must adopt practices of torture that leave no marks, such as waterboarding, lest government officials be held accountable. Busch (2000) shows that obfuscation at the level of international negotiations can help democracies achieve better trade-dispute settlement outcomes (for a similar point, see Stasavage 2004). Our question is more general: do electoral incentives increase or decrease a governments incentives to provide information? Given that all governments enjoy some degree of obfuscation, do democratic governments rely more or less on it because they face the possibility of eviction from office through the will of the majority?

We thus employ a minimalist definition of democracy. Following Schumpeter (1942) and more recently Przeworski et al. (2000), we define democracy as a regime in which the executive and the legislature are both filled by "contested elections." Contestation implies multiple parties compete, incumbents have some probability of losing the elections, and all parties comply with the results.
Conversely, dictatorships are regimes in which either the executive or the legislature are not not filled by contested elections.

The nature of our study requires this narrow definition. Nothing in this definition requires "openness": there is no requirement that governments are sufficiently willing to disclose policy relevant information. And there is no requirement for any form of transparency beyond the de minimis standards necessary for an opposition party to form and campaign. This definition is purely about the contestability of elections, and we avoid measures of regime that define democracies as transparent. Our inquiry pertains specifically to the effect of elections on transparency, so we do not want to employ a measure of democracy that conflates other features of a political system with elections.

Now, it may reasonably be argued that the existence of contested elections itself requires some degree of transparency. The government must allow some degree of freedom of assembly and speech for opposition parties to convene and campaign. Note that our theoretical interest, however, is in the dissemination of information by the governmentwhich is not necessary for the conduct of contested elections. Indeed, there are many anecdotes of governments coming to power, through both democratic and authoritarian means, only to discover that the previous administration had lied about the condition of state coffers. The conundrum for citizens is then to decide which actors are telling the truth.

We therefore employ a similarly narrow definition of "transparency." While transparency in its broadest sense may pertain to all factors that affect information flow in a polity, we confine our attention to the willingness of a government to release policyrelevant information. There is no requirement that a government employ broad protections of freedom of speech or of the press. Our measure focuses on a narrow, but crucial component of the flow of information in a society-without adequate provision of policy-relevant information, the public is unlikely to be able to hold the government to full account for its actions. Even in the presence of protections of freedom of speech and the press, a government that is able to obscure its policy decisions may effectively insulate itself from the ramifications of unpopular decisions. We thus explicitly distinguish the transparency of the electoral system from policy transparency (a distinction to which we return below in the empirical work).

Our definition is also in keeping with much of the literature on transparency. Mitchell $(1998,109)$ 
defines transparency as the dissemination of regular and accurate information. Vishwanath and Kaufmann define transparency as the "increased flow of timely and reliable economic, social and political information, which is accessible to all relevant stakeholders" (1999). A similar emphasis on the public's right to know is placed by the Fiscal Transparency Guidelines of the International Monetary Fund (IMF), which holds that "fiscal transparency requires providing comprehensive and reliable information about past, present, and future activities of government, and the availability of this information informs and improves the quality of economic policy decisions". ${ }^{6}$ Stasavage (2003) goes further and defines transparency as the announcement by the government not only of the policy decision, but also of the information used to make the decision.

Bellver and Kaufman (2005) follow Florini, making the observation we see as key to understanding transparency: "the release of information by institutions that is relevant to evaluating those institutions" (1999, 5). As Bellver and Kaufman put it, "Because transparency is a tool to facilitate the evaluation of public institutions, the information provided needs to account for their performance" $(2005,5)$. Simply put, a transparent political regime is one that provides accurate information about itself, its operations, and the country as a whole, or permits that information to be collected and made available.

As Stiglitz (2002) argues, governments have incentives both to restrict and facilitate the flow of information. Moreover, in many instances the government is the sole repository (and/or producer) of these data, and it has complete discretion as to whether to release it or not. Governments also adopt a variety of domestic institutions (laws, regulations, and procedures, such as administrative review) designed to regulate the flow of information. These include "Freedom of Information Acts," "Sunshine Policies," protections of media and speech freedoms, or more generally protections of the public's "right to know." Information is valuable to the electorate, which has an interest in knowing about government actions and processes, allocation and redistribution decisions, market barriers and restrictions, tax and subsidy incidences and so on. Not only do these factors affect the economic performance of market activities, they affect the political support the voters may offer to incumbent policy makers.

\footnotetext{
${ }^{6}$ Manual on Fiscal Transparency, the International Monetary Fund. Page 1. http://www.imf.org/external/np/pp/2007/eng/101907m. pdf accessed March 7, 2011. For a discussion, see Mosley (2003).
}

Nongovernmental organizations often lament the lack of information in the environments in which they are operating. Human Rights Watch addresses the importance of transparency as measured by the willingness of government to release data in a recent report on Angola:

"One major obstacle to public scrutiny of the
government's use of public funds has been the
government's failure to provide relevant data.
The government severely restricts information about
its activities and refuses to disclose basic information
about its revenues and expenditures. Since the early
1990s, there have been numerous allegations of
mismanagement of funds, revenue illegally bypassing
the central bank, and opaque arms purchases...
Because the Angolan public cannot obtain relevant
information, however, citizens have little way of
evaluating such allegations." (Human Rights Watch
2004, 60) This article builds on the growing concern that contested elections by themselves are insufficient to ensure high quality governance and representative policymaking, a core concern of Dahl (1971), as noted above. More recent work continues to highlight the issue. Adserà, Boix, and Payne (2003) show that both accountability and free flow of information (in the form of newspaper circulation) affect the quality of governance. Besley and Burgess (2002) show that variations in newspaper circulation affect government responsiveness in 16 Indian states. The case of Montesinos in Peru shows that the high price of bribes paid to television station owners relative to judges and bureaucrats indicates the importance of controlling the information flow if democracy is to be subverted (McMillan and Zoido 2004). ${ }^{7}$

In work closer to this article, Islam (2006) develops new measures of transparency. She focuses on (1) the timeliness of government data provision (by looking at the speed with which data appears in the WDI and the IMF's International Financial Statistics) and (2) the variation in Freedom of Information laws (FoIs) across countries. She establishes that these measures of transparency are correlated with government effectiveness.

We acknowledge that mechanisms like FoIs, timeliness, and a free privately owned press operate as sources of transparency. We argue further that countries with governments that are more willing to provide data on policy actions and decisions are more likely to be countries that permit better information flows of all kinds. It is our contention that the measure of missing data that we present below is a

\footnotetext{
${ }^{7}$ For a discussion of this case, see Saiegh (2011, chap. 7).
} 
good proxy for the lack of other kinds of available information, and therefore for (the lack of) transparency.

In our estimation section, we focus on data compiled by the World Bank. The World Bank obtains their data from other international organizations, such as the International Monetary Fund (e.g., inflation data) and the International Labour Organization (e.g., unemployment data), who in turn obtain their data directly from national governments. Much of the data are missing. Regarding inflation, for example, out of a possible total of 6,439 independent country-years for 188 independent countries from 1961 to 2002, 25\% of the observations are missing. The World Bank explains that the data are not available because governments have failed to report in a timely way or failed to report at all. In some cases, "data which have been determined to be questionable may be deleted."

In this study, we emphasize the government's willingness to permit credible measures of a wide variety of economic measures to be made available. We examine all 172 economic measures from the WDI that are reported by at least one country in every year from 1960 to $2008.9^{9}$ More economic information, released in a timely manner, allows the the public at large to make better labor allocation decisions and portfolio investment decisions.

Of course, there are other factors that influence a government's ability to report data to the World Bank, not the least of which are concerns about state capacity to collect, process, and aggregate the relevant data. The World Bank itself is aware of the weaknesses associated with this approach to managing its data collection, and in the context of the Millennium Development Goals, has instituted a global plan for increasing state capacity in data collection (the "Marrakech Action Plan for Statistics"), in the face of limited state resources for this purpose. Thus, we correct for these factors-particularly GDP per capita-when testing our principal question: do democracies disseminate more data than autocracies?

In The Moral Foundations of Politics, Shapiro (2003) makes the case that democracies are more likely than nondemocracies to converge on the truth,

\footnotetext{
${ }^{8}$ See the World Bank statements about World Development Indicators: http://data.worldbank.org/about/data-programs, accessed March 7, 2011. The WDI are also updated on an ongoing basis-data that might have been missing in earlier releases is occasionally included in later versions; this does not affect the operationalization, however, if we view data that was missing and later included as still indicative of a lack of transparency at the time electoral decisions are made.

${ }^{9}$ We consider all variables coded by the World Bank as pertaining to Economic Policy and Debt to be "economic measures."
}

but the argument offers neither theory nor evidence. Elsewhere, democracies are simply assumed to be more transparent, or democracy is used explicitly as a proxy for transparency (for example, Broz 2002). Is it true that democracies are more likely to provide accurate information than nondemocracies? In the following sections we investigate this question both theoretically and empirically.

\section{The Effect of Democracy on Transparency}

To highlight the incentives for democratic polities to be more transparent, we develop a simple demonstrative model. Democracy is captured as the degree to which the will of the voters is reflected in whether incumbents are reelected. Moreover, we give the leaders in all regime types the same preferences over transparency-which is that they always prefer less to more. In this way, we do not make transparency an assumed feature of democratic polities or the preferences of democratic leaders; it rather emerges in equilibrium. Social welfare increases in transparency, and the inclination of the voters to reelect the incumbent increases with social welfare; transparency, therefore, affects reelection probabilities.

In polities where the will of the voters is irrelevant, elections have no effect on government's choice of the level of transparency. In polities where the will of the voters is determinative, the welfare enhancing effect of more precise information outweighs the disutility from a more open government for the regime leaders. Hence polities with greater electoral accountability offer more precise public signals.

Voter behavior here is conditional on the voter's welfare. ${ }^{10}$ We are agnostic as to whether voters are rewarding or punishing their executives for past performance (retrospective voting behavior; Ferejohn 1986; Fiorina 1981), or instead, using the performance of the economy (and their welfare) as a signal of the competence and/or preferences of the executive (as in prospective voting models; Lewis-Beck 1988). In either case, current economic conditions, as indicated by the current welfare, determine the share of the population who vote for the incumbent. Voting is therefore largely "economic" or "pocketbook" (Hibbs 1982; Lewis-Beck and Stegmaier 2009). Furthermore, the model structure we assume is

\footnotetext{
${ }^{10}$ Voters may be sociotropic or not-there is little distinction here between the welfare of the voter and that of society as a whole (Bartels 2008)
} 
general enough to permit the executive to respond to the interests of groups instrumental in maintaining the executive in office, rather than the electorate as a whole (Bueno de Mesquita et al. 2003).

Consider a polity with a continuum of individuals indexed by $i$ on the unit interval $[0,1]$. In this simple one-shot game, the government moves first by determining the degree of transparency (in a manner to be made precise below). The government's action is not observed by the voters. Voters receive a public signal; they then choose their actions. An election is held and the game ends.

Each voter chooses an action $a_{i}$, and let $a$ denote a profile of actions for all voters. The loss function for voter $i$ is $u_{i}(a, \theta)=-\left(a_{i}-\theta\right)^{2}$. Voters choose their actions to match the policy environment, $\theta$, as closely as possible. We can think of $\theta$ as some policy-relevant variable over which the voters must take an action to accommodate this policy. In this setup, voters have a preference for more information about the value of $\theta .^{11}$

For example, workers have incentives to provide only as much labor such that the real wage is equal to the marginal disutility of effort. The real wage, of course, is determined by the inflation rate, a variable over which there may be more or less available information. As another example, a firm must choose its level of inputs (and hence output) based on its expectations about the price level or aggregate demand, and the government may choose to provide more or less information about its spending behavior. Or, a portfolio investor must match the mix of assets to a well-diversified portfolio, which depends on the expected returns on a variety of risky assets. The government exercises some influence over some relevant interest rates and can provide more or less information about its intentions. In all these instances, the voter has an incentive to take an action that matches the state of the policy environment. But the voter is imperfectly informed about the state of this environment, and government chooses the degree to which this information is available.

Each agent receives the same public signal $y$, about the state of the policy environment, $\theta$, with $y=$ $\theta+\eta$ where $\eta$ is distributed symmetrically around mean zero and variance $\sigma^{2}$. It will be useful to denote

\footnotetext{
${ }^{11}$ We take this policy environment variable $\theta$ to be exogenous; ultimately, the policy is chosen by the government, and voters may be able to estimate its value from information other than received via the public signal (such as past policy choices). We consider here only a one-shot game where these concerns do not apply.
}

the "precision" of the signal as $\alpha=\frac{1}{\sigma^{2}}$. It is this level of precision $\alpha$ which will be the choice variable for the government. ${ }^{12}$

Social welfare is the average utility of all individuals. Hence we have $W(a, \theta)=-\int_{0}^{1}\left(a_{i}-\theta\right)^{2} d i$. The government, however, is not purely interested in maximizing social welfare. We assume that governments wish to hold onto office. At the end of the period, there is an election. We simply model the outcome of the election as increasing in social welfare-higher social welfare means a greater probability of winning reelection: $\operatorname{Pr}\{$ reelection $\}=P(W(a, \theta))$ with $P^{\prime}>0$ and $P^{\prime \prime}<0$.

The degree to which the "will of the people" is reflected in who actually holds office is exogenous and is our measure of political regime. Following Mansfield, Milner, and Rosendorff (2002), we characterize each polity by a scalar $\Delta \in[0,1]$ which captures the degree to which elections are binding on the executive. Then the government's payoff is $G(a, \alpha, \theta)=\Delta P(W(a, \theta))+(1-\Delta)-\frac{1}{2} \alpha^{2}$.

If the voters' will is always honored, we have $\Delta=1$; a pure autocracy has $\Delta=0$. We permit a continuous measure of the degree to which the executive is bound by elections, and the typical government's welfare is a convex combination of the returns to a pure democracy, and a pure autocracy. In a pure democracy, social welfare has the largest weight in the government's objective function, since the will of the electorate is determinative. On the other hand when social welfare has no impact on the likelihood that the executive retains office, the government's concerns over transparency (or a lack thereof) become determinative-the pure autocracy case.

The last term in the government's objective function reflects the disutility all leaders face from transparency. The government has a natural tendency towards obfuscation - this permits questionable policies to be blamed on others; rent redistributions to

\footnotetext{
${ }^{12}$ It may at first seem odd that we model uncertainty as symmetrically distributed with mean zero, given that governments' efforts at obfuscation nearly always reflect some form of bias. However, so long as the government's incentive to dissemble is known, the public-in equilibrium-will be able to account for such bias in policy pronouncements. In most models of information transmission (e.g., Crawford and Sobel 1982), higher levels of bias on the part of the sender translate into greater uncertainty on the part of the receiver. They do not lead to biased beliefs on the part of the receiver. Rather than burdening our model with undue complexity by fully modeling this interaction, we rely on the assumption that uncertainty is symmetrically distributed with mean zero as a reduced form.
} 
be only weakly observed or not all; and even outright corruption that flies under the radar. All regimes have this tendency, and we do not assume that it varies with regime type ${ }^{13}$

A Bayesian equilibrium to this game is a pair $(a, \alpha)$ such that each is playing a best response (Fudenberg and Tirole 1991). We solve the game by backwards induction.

Given any $\alpha$, each voter must choose $a_{i}$ in order to maximize his or her expected utility given the signal $y$. Then

$$
E\left(u_{i}(a, \theta) \mid y\right)=-a_{i}^{2}+2 a_{i} E(\theta \mid y)-E\left(\theta^{2} \mid y\right) .
$$

The first-order condition yields $a_{i}=E(\theta \mid y)=y$.

Conditional on any $\theta$ therefore, we can compute expected social welfare. Recall that $W(a, \theta)=$ $-\int_{0}^{1}\left(a_{i}-\theta\right)^{2} d i=-(y-\theta)^{2}$. Substituting $y=\theta+\eta$ we have $W(a, \theta)=-\eta^{2}$.

Now that we know how the voters behave, consider the government's problem. It must solve

$$
\max _{\alpha} E G(a, \alpha, \theta) \text { subject to } a_{i}=E(\theta \mid y)=y .
$$

Then $E G(a, \alpha, \theta)=\Delta E P\left(-\eta^{2}\right)+(1-\Delta)-\frac{1}{2} \alpha^{2}$.

To make the solution to this problem tractable, we make two distributional assumptions. Assume firstly that the electoral probability follows an exponential distribution with density: $P(x ; \beta)=\beta e^{-\beta x}$ for any $x>0$. And assume secondly that $\eta$ has a normal distribution (with mean 0 and variance $\frac{1}{\alpha}$ ). To ensure the second-order conditions are satisfied, we also assume that $\alpha>2 \beta$. That is, the precision of the signal is always bounded above by (half of) the mean of the electoral probability distribution. We show in Appendix A, that for any arbitrarily large scalar $C \gg 0$ :

Proposition 1. The Nash equilibrium $(a, \alpha)$ is $\left(y,\left(\beta+\sqrt{\beta^{2}+\left(\Delta \beta e^{-\beta C}\right)^{\frac{2}{3}}}\right)\right)$.

We can now consider the comparative statics on the equilibrium level of precision as a function of the degree of electoral accountability.

Proposition 2. The equilibrium level of precision rises with electoral accountability, $\frac{\partial \alpha}{\partial \Delta} \geq 0$.

\footnotetext{
${ }^{13}$ Ferejohn (1986) argues that elected officials have a significant informational advantage over the voters that permits the officials to engage in opportunistic behaviors, behaviors that can be mitigated by enhancing accountability. Ferejohn (1999) offers a related model in which the degree of monitoring the voters can undertake is endogenously determined and chosen optimally by the policymaker.
}

As the degree of electoral accountability rises, the weight of social welfare in the government's objective function rises. Social welfare here is a function of transparency, as greater transparency allows voters to more precisely match their behaviors to the policy environment. As social welfare is more determinative of a the government's survival in office when a government is more democratic (i.e., as $\Delta$ rises), the government is more willing to disseminate policy-relevant information. Notice that the more precision is provided to placate the voters, who are more important in determining whether the executive retains office. All governments are assumed to suffer an equivalent cost to transparency, but the marginal benefits to data dissemination rise in line with democracy.

\section{Evidence}

Proposition 2 holds that the level of precision with which economic policies are announced is increasing in the level of electoral accountability $\frac{\partial \alpha}{\partial \Delta}>0$. As the level of electoral accountability rises, so too does the government's interest in ensuring that economic agents-e.g., investors-make optimal investment and consumption decisions. Therefore, a greater responsiveness to the interests of the voters induces governments to disclose more relevant economic data.

\section{Data Description}

We measure the government's willingness to disclose economic data directly. Our measure of a government's willingness to disclose economic data is based on the reporting of the World Bank's World Development Indicators (World Bank 2010). We take the absence of data from the WDI as indicative of a government's unwillingness to disclose economic data.

The World Bank assembles its WDI data series based on information provided by other international organizations. These organizations, in turn, obtain their data directly from national governments. If national governments fail to disclose information in a timely manner, or fail to disclose it at all, countryyear observations will be missing from the WDI dataset. In some instances, the World Bank leaves observations in the WDI as missing because information provided by national governments is deemed to be "questionable." 
This measure relates closely to the theoretical conception of transparency used in our model. In our model we treat transparency as reducing the variance (increasing the precision, $\alpha$ ) of the public's perception of the policy environment. One may think of the public as holding prior beliefs regarding the policy environment-credible policy pronouncements by the government cause members of the public to update these beliefs to form more confident (precise) posteriors. In the absence of any data dissemination, no updating takes place and beliefs remain diffuse. Noncredible policy pronouncements also produce little updating - and, as noted above, the World Bank will exclude noncredible data from the WDI. ${ }^{14}$ Thus, the missingness of data from the WDI may reasonably be taken as a proxy of the imprecision of the public's beliefs regarding a given country's policy environment.

To construct our index of transparency, we rely on all variables related to "Economic Policy and Debt" in the WDI database that are reported by at least one country in every year from 1960 to 2008. The World Bank classifies variables according to the policies to which they relate on their website, and we defer to their classification scheme. ${ }^{15}$ As our theoretical discussion pertains most directly to economic policy, we restrict our attention to variables listed in the Economic Policy and Debt category.

There are 172 variables in this category of the WDI that are consistently measured between 1960 and 2008. Our index measures the fraction of these 172 variables reported by a given country in a given year. A country that does not report any data to the WDI is thus given a measure 0 ; while one that reports all 172 variables is given a 1 . A country-year for which 86 variables are observed, and another 86 are coded as missing would be given an index score of 0.5 .

Our measure of transparency thus directly reflects government decisions to release accurate economic data. Since the theory developed above pertains to governments' willingness to report such data, our measure possesses a high degree of content validity (Carmines and Zeller 1979). This validity-relative to the theoretical measure of interest-stands in contrast

\footnotetext{
${ }^{14}$ The World Bank adheres to the General Data Dissemination System (GDSS) framework and collaborates with the IMF on the Data Quality Assessment Framework (DQAF) to monitor the quality of national statistical agencies' reporting. http://data. worldbank.org/about/data-overview/data-quality-and-effectiveness accessed March 7, 2011.

${ }^{15}$ See http://databank.worldbank.org/ddp/home.do, accessed March 7, 2011. Other categories include Education, Environment, Financial Sector, Health, Infrastructure, Labor and Social Protection, Poverty, Private Sector and Trade, and Public Sector.
}

\section{FIgURE 1 Histogram of the Transparency Index}

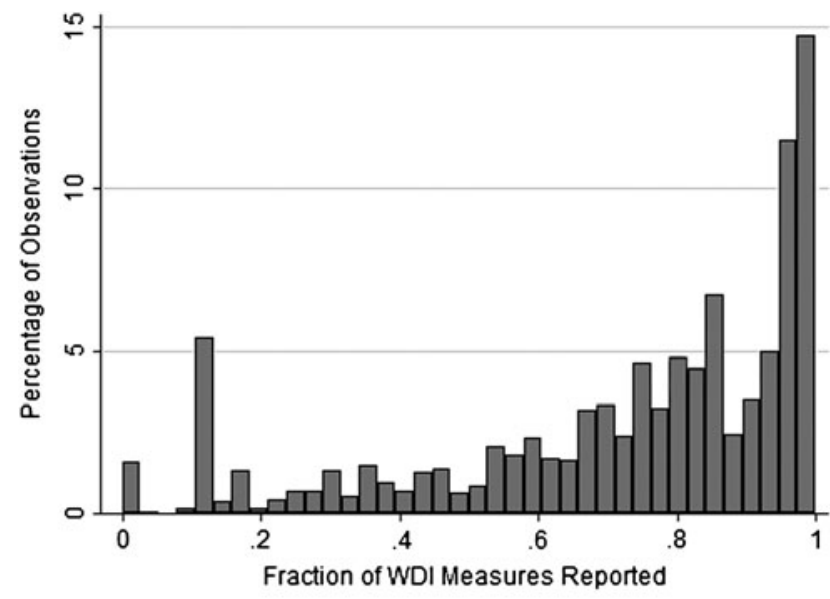

A histogram of the fraction of WDI variables with nonmissing data across country-years. The $\mathrm{x}$-axis reports the fraction of WDI variables with nonmissing data, while the $y$-axis denotes the percentage of observations with a given transparency score.

to alternative measures of transparency. For instance, Freedom House's Freedom of the Press index relies of subjective judgements pertaining to a country's (1) laws and regulations that influence media content, (2) degree of political control over the news media, and (3) structure of media ownership. ${ }^{16}$ Beyond the problem of subjectivity, all three considerations affect the free flow of information; but none directly pertain to the government's decision to release or withhold data. A more direct measure of the flow informationnewspaper circulation-is often used as a proxy for transparency (see, for instance, Adserà, Boix, and Payne 2003; Besley and Burgess 2002). Again, however, this measure need not capture the willingness of the government to disseminate information.

The fraction of WDI variables reported for each country-year varies between zero and one in our sample. Countries vary substantially in the extent of reporting. In the median country-year, $80.8 \%$ of WDI variables are reported, while the mean observation reports $72.1 \%$. A histogram of our transparency measure is displayed in Figure 1.

To assess whether elections increase the willingness of governments to report economic data, we regress our transparency index on different measures of political regime. We restrict attention to measures that reflect an institutional-minimalist-conception of democracy. Measures of the "quality" of democracy

\footnotetext{
${ }^{16}$ See http://freedomhouse.org/images/File/fop/2010/methodology/ 2010-fina15may10.pdf accessed August 15, 2011.
} 
Table 1 Summary Statistics

\begin{tabular}{llcccc}
\hline Variable Name & Mean & Stand. Dev. & Min. & Max. & N \\
\hline Transparency & 0.721 & 0.272 & 0 & 1 & 7249 \\
DD democracy & 0.433 & 0.496 & 0 & 1 & 7234 \\
Polity 2 & 0.385 & 7.50 & -10 & 10 & 6244 \\
GDP per capita & 8.86 & 10.8 & 0.153 & 97.8 & 6962 \\
Under IMF & 0.29 & 0.45 & 0 & 1 & 6641 \\
\hline
\end{tabular}

(e.g., the Freedom House index) may incorporate transparency in the definition of a democratic government. Analysis of such a democracy measure would capture a tautological association between our outcome (transparency) and explanatory variables. Hence our theoretical concept, $\Delta$ is best captured using minimalist definition of democracy-one in which the contestability of elections is primary.

We employ two indices of democracy in our empirical analysis. The first is the DD measure of democracy (Cheibub, Ghandi, and Vreeland 2010). ${ }^{17}$ This index classifies a regime as a democracy if both the executive and the legislature are filled by "contested elections". ${ }^{18}$ This democracy measure is binary, with a value of 1 indicating that a country-year is a democracy.

For robustness, we rely on a second index is drawn from the Polity 4 dataset (Marshall and Jaggers, 2000). We employ the polity variable from this dataset, which ranks country-years on an index ranging from -10 to 10 in order of increasing levels of democracy. Countries are ranked according to institutional criteria which include the competitiveness of executive recruitment, the openness of executive recruitment, the degree of constraints on the chief executive, and the competitiveness of political participation. Of concern might be that the electoral components of this index are coded with respect to "the transparency of the electoral process" (Marshall and Jaggers 2000, 61). There is no reference in the codebook, however, to the transparency of policymaking or the dissemination of data, so there

\footnotetext{
${ }^{17}$ This index was previously referred to as the ACLP measure of democracy, after the authors of the original data release (Alvarez et al. 1996).

${ }^{18}$ Elections are only considered contested if multiple political parties participate, and there has been at least one transfer of power from one political party to another under this political regime.
}

is not a tautological association between this variable and the dissemination of policy related data. As we discussed in the second section above, we draw an explicit distinction between the transparency of the electoral process and policy transparency.

We also employ a parsimonious set of controls in multiple regression specifications. Our specification is parsimonious precisely because our dependent variable measures the degree of data availability. As our set of controls grows more extensive, we are increasingly likely to censor observations of our outcome variable. Such censoring will tend to eliminate country-years that report a small fraction of WDI variables from our dataset, potentially biasing results.

Two confounding variables are included in our empirical specifications. One is per capita GDP, measured in thousands of PPP weighted constant dollars and drawn from the Penn World Table version 6.3 (Heston, Summers, and Aten 2009). Note that GDP per capita is likely to relate to the ability of governments to collect and disseminate high-quality statistical data. Since democracies have, on average, higher incomes than nondemocracies, failure to control for GDP per capita may bias the coefficient on our democracy measures upwards. Contrastingly, the World Bank's mission requires it to focus its attention on developing countries, which may bias the collection of certain economic data. If the World Bank devotes greater attention and effort to collecting data from developing countries, failure to control for GDP per capita in our specifications may bias our estimates of the association between democracy and transparency downwards. The Penn World Table includes observations for 190 countries from 1950 to 2007, with no missing observations. Thus, the use of this control variable does not lead to censoring in our outcome measure.

We additionally include a control for participation in IMF programs. The IMF often requires that governments receiving support publish relevant economic data. A pillar of its Fiscal Transparency 
TABLE 2 The Relationship Between Transparency and the DD Score

\begin{tabular}{|c|c|c|c|c|c|c|}
\hline & $\begin{array}{c}\text { Model } \\
1\end{array}$ & $\begin{array}{c}\text { Model } \\
2\end{array}$ & $\begin{array}{c}\text { Model } \\
3 \\
\end{array}$ & $\begin{array}{c}\text { Model } \\
4\end{array}$ & $\begin{array}{c}\text { Model } \\
5\end{array}$ & $\begin{array}{c}\text { Model } \\
6\end{array}$ \\
\hline DD democracy & $\begin{array}{c}0.131^{\star * *} \\
{[0.085,0.177]}\end{array}$ & $\begin{array}{c}0.087^{\star * *} \\
{[0.044,0.130]}\end{array}$ & $\begin{array}{c}0.095^{* * *} \\
{[0.051,0.138]}\end{array}$ & $\begin{array}{c}0.097^{* * *} \\
{[0.053,0.141]}\end{array}$ & $\begin{array}{c}0.148^{\star * *} \\
{[0.097,0.200]}\end{array}$ & $\begin{array}{c}0.029 \\
{[-0.017,0.075]}\end{array}$ \\
\hline GDP per capita & & & $\begin{array}{c}-0.003^{\star \star} \\
{[-0.005,-0.001]}\end{array}$ & $\begin{array}{c}-0.002 \\
{[-0.005,0.000]}\end{array}$ & $\begin{array}{c}0.011^{* * *} \\
{[0.005,0.017]}\end{array}$ & $\begin{array}{c}-0.001 \\
{[-0.003,0.001]}\end{array}$ \\
\hline Under IMF & & & & $\begin{array}{c}0.097^{* * *} \\
{[0.061,0.133]}\end{array}$ & $\begin{array}{c}0.105^{* * *} \\
{[0.070,0.140]}\end{array}$ & $\begin{array}{c}0.054^{* * *} \\
{[0.029,0.079]}\end{array}$ \\
\hline $\begin{array}{l}\text { Cubic Time } \\
\text { Polynomial }\end{array}$ & & $\sqrt{ }$ & $\sqrt{ }$ & $\sqrt{ }$ & & $\checkmark$ \\
\hline $\begin{array}{l}\text { Country Fixed } \\
\text { Effects }\end{array}$ & & & & & $\sqrt{ }$ & $\sqrt{ }$ \\
\hline $\begin{array}{l}\text { Regression Std. } \\
\text { Error }\end{array}$ & 0.263 & 0.226 & 0.216 & 0.212 & 0.176 & 0.130 \\
\hline $\mathrm{N}$ & 7234 & 7234 & 6956 & 6379 & 6379 & 6379 \\
\hline
\end{tabular}

Results of an OLS regression of the fraction of WDI variables reported in a given country-year against the DD measure of democracy and controls. Coefficient estimates are reported with 95 percent confidence intervals (in brackets). ${ }^{\star}$ denotes statistical significance at the 95 percent level, ${ }^{* *}$ denotes significance at the 99 percent level, and ${ }^{\star * *}$ denotes significance at the 99.9 percent level. Controls for a cubic polynomial of time and for country-specific fixed-effects are denoted by check marks. All standard errors are clustered at the country-level.

Guidelines is the "Public Availability of Information," particularly the "publishing of comprehensive fiscal information."19 Since the IMF has been disproportionately likely to extend programs to dictatorships during parts of its history (Vreeland 2003b), failure to control for this potential confound may bias our coefficient of interest towards zero.

We also include controls for cubic time trends in our specifications, to ensure that patterns in the evolution of transparency and democracy do not induce a spurious correlation in our results (Carter and Signorino 2007). Table 1 reports the summary statistics of the variables described above.

\section{Empirical Model and Results}

To assess the relationship between democracy and the dissemination of economic data, we fit an OLS regression of the percentage of WDI variables reported in a given country-year on the democracy indexes in alternative specifications. This regression is of the form

$$
\text { transparency }=\delta \text { democracy }+\mathrm{X} \gamma+\epsilon
$$

where $\epsilon \sim N(0, \Sigma)$ and $\Sigma$ is structured to allow for clustering of the standard errors within countries.

\footnotetext{
${ }^{19}$ Manual on Fiscal Transparency, the International Monetary Fund. Page 6. http://www.imf.org/external/np/pp/2007/eng/ 101907m.pdf accessed March 7, 2011.
}

Thus, off-diagonal elements of $\Sigma$ are not constrained to zero. X captures a matrix of control variables, while $\gamma$ is a column vector containing the coefficient values on these controls. $\delta$-a scalar-is our value of central interest. It captures the association between democracy and transparency and is predicted to be positive.

In our simplest specifications, we assess the bivariate relationship between the fraction of WDI variables reported and our democracy indicators. We then iteratively add controls for cubic time polynomials, GDP per capita, IMF status, and country fixed effects. The results of these regressions are reported in Tables 2 and 3.

Both the DD and the Polity measures are correlated with the fraction of WDI variables reported. A change from an autocracy to a democracy, by the DD definition, increases the fraction of nonmissing WDI variables by 13 percentage points. An increase in the Polity 2 score from -10 to 10 (from most autocratic to the most democratic of measures) increases the fraction of WDI variables reported by 20 percentage points. This change is quite large, amounting to a roughly one-standard-deviation change in the level of transparency. Both associations are also statistically significant at the $99.9 \%$ level.

The magnitude of this relationship in the raw data is diminished when we control for time trends. Both transparency and democracy have been trending upwards over time, inducing a spurious correlation 
Table 3 The Relationship Between Transparency and the Polity Score

\begin{tabular}{|c|c|c|c|c|c|c|}
\hline & Model 1 & Model 2 & Model 3 & Model 4 & Model 5 & Model 6 \\
\hline Polity 2 & $\begin{array}{c}0.010^{* * *} \\
{[0.007,0.014]}\end{array}$ & $\begin{array}{c}0.007^{\star * \star} \\
{[0.004,0.011]}\end{array}$ & $\begin{array}{c}0.008^{\star * *} \\
{[0.005,0.011]}\end{array}$ & $\begin{array}{c}0.008^{\star * *} \\
{[0.005,0.011]}\end{array}$ & $\begin{array}{c}0.012^{* * *} \\
{[0.008,0.016]}\end{array}$ & $\begin{array}{c}0.003^{*} \\
{[0.000,0.006]}\end{array}$ \\
\hline GDP per capita & & & $\begin{array}{c}-0.004^{\star * *} \\
{[-0.006,-0.002]}\end{array}$ & $\begin{array}{c}-0.003^{\star} \\
{[-0.006,-0.001]}\end{array}$ & $\begin{array}{c}0.011^{\star \star} \\
{[0.004,0.018]}\end{array}$ & $\begin{array}{c}0.000 \\
{[-0.002,0.002]}\end{array}$ \\
\hline Under IMF & & & & $\begin{array}{c}0.081^{\star * *} \\
{[0.045,0.117]}\end{array}$ & $\begin{array}{c}0.101^{* * *} \\
{[0.067,0.135]}\end{array}$ & $\begin{array}{c}0.054^{* * *} \\
{[0.028,0.079]}\end{array}$ \\
\hline $\begin{array}{l}\text { Cubic Time } \\
\text { Polynomial }\end{array}$ & & $\sqrt{ }$ & $\sqrt{ }$ & $\checkmark$ & & $\checkmark$ \\
\hline $\begin{array}{l}\text { Country Fixed } \\
\text { Effects }\end{array}$ & & & & & $\checkmark$ & $\checkmark$ \\
\hline $\begin{array}{l}\text { Regression Std. } \\
\text { Error }\end{array}$ & 0.252 & 0.211 & 0.203 & 0.201 & 0.174 & 0.127 \\
\hline $\mathrm{N}$ & 6244 & 6244 & 6044 & 5566 & 5566 & 5566 \\
\hline
\end{tabular}

Results of an OLS regression of the fraction of WDI variables reported in a given country-year against the Polity 2 measure of democracy and controls. Coefficient estimates are reported with 95 percent confidence intervals (in brackets). ${ }^{*}$ denotes statistical significance at the 95 percent level, ${ }^{* *}$ denotes significance at the 99 percent level, and ${ }^{* * *}$ denotes significance at the 99.9 percent level. Controls for a cubic polynomial of time and for country-specific fixed-effects are denoted by check marks. All standard errors are clustered at the country-level.

between our explanatory and outcome variables. Still, after controlling for a cubic polynomial of time, the relationship between democracy and transparency is significant at the $99.9 \%$ level.

IMF programs have the expected positive association with disclosure, while the coefficient on GDP per capita is, surprisingly, inconsistent in sign. It appears that the effects of the World Bank's selective measurement of variables trumps any difference across countries due to their ability to collect and disseminate high-quality data. Models 2, 3, 4, and 6 also control for time trends.

Model 6 in both Table 2 and Table 3 includes country-level fixed effects in the specification. Note that if a country never changes in DD or Polity scores, then these variables will be perfectly collinear with the country fixed-effects. The coefficient on our democracy term in these models is therefore only identified by those countries that experienced regime change, according to either the DD or the Polity 2 measures. ${ }^{20}$ Since a country is more likely to vary in its Polity 2 scores over time than it is to vary in its DD scores, we lose fewer observations in the Polity model with country fixed-effects than we do in the DD model. In the former model, the coefficient on the Polity 2 score is positive and significant at the $95 \%$ level. In the latter, the coefficient is positive, but not significant at conventional levels $(p=0.22)$.

\footnotetext{
${ }^{20}$ Since developed democracies rarely vary on either measure, it is unlikely that our results are driven by this group of countries alone.
}

The inclusion of country fixed-effects in the specification is advantageous insofar as they reduce the danger of omitted variable bias. Time-invariant factors that differ across countries are effectively controlled for when using fixed effects, reducing the danger of confounding (Green, Kim, and Yoon 2001). But, the inclusion of country fixed effects ensures that the coefficients on the democracy indexes will only reflect the association between democracy and transparency in countries that undergo changes in democracy values (Beck and Katz 2001). It is possible that countries that undergo changes in regime type will differ from otherwise similar countries in a systematic fashion. For instance, autocracies that eventually transition to democracy may be more transparent than autocracies that never undergo a transition. Similarly, democracies that transition to autocracy may be less transparent than other democracies. To the extent this is the case, the coefficients on the democracy indexes in our regressions that control for country fixed effects will be compressed towards zero.

We therefore report estimates from models both with and without country fixed effects and find a positive association between democracy and transparency in all models. This association is statistically significant at conventional levels in all models save Model 6 in Table 2, which employs fixed effects and cubic time polynomials with the DD democracy indicator. But, the DD democracy values change infrequently over time and only alter at all in 39\% of 
countries in the sample. ${ }^{21}$ We conclude that these estimates offer support for the theory advanced above.

As a final robustness test, one might consider a standard measure of transparency: the Transparency Index of the International Country Risk Guide (ICRG) produced by Political Risk Services (Knack and Keefer 1995). We avoid this measure because it intentionally conflates corruption, law and order, bureaucratic quality and expropriation risk-all of which may overlap with measures of political regime. Thus, there may be a tautological association between the ICRG measure and democracy. That said, Rosendorff and Doces (2006) find strong causal links between the this transparency index and the polity measure-giving support to the notion that the relationship established here is robust.

\section{Conclusion}

Our substantive conclusion is straightforward: electoral competition is associated with greater transparency. Despite electoral incentives towards obfuscation, democratic governments are more likely to release policyrelevant data than are autocracies. We provide both theoretical arguments of why this is so as well as evidence from data provided by governments to the World Bank. This finding confirms what has often been taken for granted about democracy and transparency. Beyond this, however, our results have at least two methodological implications for other research on democracy.

The first implication regards the definition of democracy. Debate about the most appropriate measure for political regime abounds. The debate is waged today by proponents of various indicators of democracy, but it stretches back throughout modern political science. Dahl (1971), for example, took issue with the minimalist conception of democracy of Schumpeter (1942) when he first introduced his concept of "polyarchy." Dahl argued that contested elections alone were not sufficient to define democracy, because "responsiveness" was also required. And for there to be responsiveness, Dahl listed several guarantees that were necessary, including, for example, the free flow of information.

\footnotetext{
${ }^{21} \mathrm{We}$ are less concerned with the dangers of the fixed-effects estimation procedure when using the Polity measure of democracy, as the finer gradation of this model allows for greater variation over time. See Vreeland (2003a) for a discussion of a continuous measure of a minimalist conception of democracy.
}

Przeworski et al. (2000) proposed a return to the minimalist definition of democracy. They make this suggestion not because other features—such as those listed by Dahl-are unimportant, but because the relationships among these various other features should be examined not assumed. So, for example, rather than require the free flow of information to be a defining feature of democracy, they restrict the definition of democracy to cover only elections.

We show that there is a relationship between elections and information. The most transparent regimes are those in which the key offices of the executive and the legislature are filled through contested elections. This relationship is not simply imposed by the definition of democracy, but rather reflects the equilibrium behavior self-interested governments. We establish that this relationship holds both theoretically and empirically. So the minimalist definition of democracy actually covers more territory than just elections.

Note that this does not imply that all democracies will practice transparency in all policy areas. As previous research shows, democratic governments have incentives to optimize policy choices given varying degrees of opacity across the policy areas (Mani and Mukand 2007), and these governments may even have incentives to optimize obfuscation itself (Kono 2006; Rejali 2007). Still, we show that electoral incentives-particularly the phenomenon of economic voting-drive democracies towards greater openness. And we demonstrate empirically that the incentives that drive democracies to release data trump whatever motives they have to obfuscate.

This leads us to a second methodological concern that this article addresses: the nonrandom nature of missing data. Whether information about a country is available is no accident. The availability, precision, and quality of data is driven, in part, by political institutions. The implication for cross-national research on democracy is clear: missing data cannot be ignored. Researchers studying the causes and consequences of political regimes must be wary that their empirical findings are not driven simply by the subset of observations for which data are available. Fortunately, political scientists have been taking the problems of missing data more seriously. The datagenerating process that produces missing values can be explicitly modeled to account for the potential biases resulting data that are not missing completely at random (Honaker and King 2010; King et al. 2001). Our findings indicate that political institutions-particularly democracy-must be included in such models. Beyond this concern, however, our paper shows that missing 
data is not just a problem to be overcome. In many cases, missing data may also be a phenomenon worthy of explanation.

\section{Acknowledgments}

Thanks are due to participants at workshop and presentations at NYU, the International Political Economy Seminar at Princeton, the UCLA International Institute, Syracuse University, the International Political Economy Society conference, the Midwest Political Science Association conference, the Latin American Studies Association conference, the American Political Science Association conference; and to David Singer and Sebastian Saiegh for comments on earlier versions.

\section{A Appendix}

\section{A.1 Proof of Proposition 1}

Proof. From Equation (1), the voters are behaving optimally when they set $a_{i}=y$ for all $i$. Consider now the government's payoffs, taking voter behavior as given:

$$
\begin{aligned}
E(G(a, \theta, \alpha) \mid \theta) & =\Delta E\left(P\left(-\eta^{2}\right)\right)+(1-\Delta)-\frac{1}{2} \alpha^{2} \\
& =\Delta \int P\left(-\eta^{2}\right) f(\eta) d \eta+(1-\Delta)-\frac{1}{2} \alpha^{2}
\end{aligned}
$$

Consider the exponential distribution with cdf $P(x)=1-e^{-\beta x}$ for any $x>0$. We apply the monotonic transformation, defining $w(a, \theta)=W(a, \theta)+C=$ $C-\eta^{2}=x>0$, and we let $P$ instead be a function of $w(a, \theta)$. Then $P(w(a, \theta))=1-e^{-\beta C} e^{\beta \eta^{2}}$. Let $f$ be normal with $f(\eta)=\frac{\sqrt{\alpha}}{\sqrt{2 \pi}} e^{-\frac{1}{2} \alpha \eta^{2}}$.

Then

$$
\begin{aligned}
E(G(a, \theta, \alpha) \mid \theta)= & \Delta \int\left(1-e^{-\beta C} e^{\beta \eta^{2}}\right) \\
& \times \frac{\sqrt{\alpha}}{\sqrt{2 \pi}} e^{-\frac{1}{2} \alpha \eta^{2}} d \eta+(1-\Delta) \\
& -\frac{1}{2} \alpha^{2} \\
= & \Delta\left[1-e^{-\beta C} \frac{\sqrt{\alpha}}{\sqrt{2 \pi}} \int e^{-\left(\frac{1}{2} \alpha-\beta\right) \eta^{2}} d \eta\right] \\
& +(1-\Delta)-\frac{1}{2} \alpha^{2}
\end{aligned}
$$

$$
\begin{aligned}
& \text { Now } \begin{aligned}
\int_{-\infty}^{\infty} e^{-k x^{2}} d x= & \frac{\sqrt{\pi}}{\sqrt{k}} . \text { Then } \\
E(G(a, \theta, \alpha) \mid \theta)= & \Delta\left[1-e^{-\beta C}\left(\frac{\frac{1}{2} \alpha}{\frac{1}{2} \alpha-\beta}\right)^{\frac{1}{2}}\right] \\
& +(1-\Delta)-\frac{1}{2} \alpha^{2}
\end{aligned}
\end{aligned}
$$

Maximizing over $\alpha$, we have $\frac{d}{d \alpha} E G(a, \theta, \alpha)=$ $-\Delta e^{-\beta C} \frac{d}{d \alpha}\left(\frac{\frac{1}{2} \alpha}{\frac{1}{2} \alpha-\beta}\right)^{\frac{1}{2}}-\alpha$. Now $\frac{d}{d \alpha}\left(\frac{\frac{1}{2} \alpha}{\frac{1}{2} \alpha-\beta}\right)^{\frac{1}{2}}=-\frac{\beta}{4}\left(\frac{1}{2} \alpha-\right.$ $\beta)^{-\frac{3}{2}\left(\frac{\alpha}{2}\right)^{-\frac{1}{2}}}$. Then $\quad \frac{d}{d \alpha} E G(a, \theta, \alpha)=\frac{\Delta}{4} \beta e^{-\beta C}$ $\left(\frac{1}{2} \alpha-\beta\right)^{-\frac{3}{2}}\left(\frac{\alpha}{2}\right)^{-\frac{1}{2}}-\alpha=0$.

Solving for $\alpha$, yields two solutions, $\left(\beta+\sqrt{\beta^{2}+\left(\Delta \frac{\beta}{e^{C \beta}}\right)^{\frac{2}{3}}}, \beta-\sqrt{\beta^{2}+\left(\Delta \frac{\beta}{e^{C \beta}}\right)^{\frac{2}{3}}}\right)$.

Checking the second order condition $\frac{d}{d \alpha} \frac{d}{d \alpha} E G(a, \theta, \alpha)=\frac{\Delta}{8} \beta e^{-\beta C}(\alpha-2 \beta)^{-\frac{5}{2}} \alpha^{-\frac{3}{2}}(\beta-2 \alpha)$

-1 . A sufficient condition for this to be negative is $\alpha-2 \beta>0$. Then of the two solutions, only $\beta+\sqrt{\beta^{2}+\left(\Delta \frac{\beta}{e^{C \beta}}\right)^{\frac{2}{3}}}$ satisfies $\alpha-2 \beta>0$.

\section{A.2 Proof of Proposition 2}

Proof. From the government's first order condition, $\frac{d}{d \alpha} E G(a, \theta, \alpha)=0$. Totally differentiating this yields $\frac{d}{d \alpha} \frac{d}{d \alpha} E G(a, \theta, \alpha) d \alpha+\frac{d}{d \Delta} \frac{d}{d \alpha} E G(a, \theta, \alpha) d \Delta=0$. Then $\frac{d \alpha}{d \Delta}=-\frac{\frac{d}{d \Delta} \frac{d}{d \alpha} E G(a, \theta, \alpha)}{\frac{d^{2}}{d \alpha^{2}} E G(a, \theta, \alpha)}$. From the previous proof, $\alpha$ $-2 \beta>0$ is sufficient for $\frac{d^{2}}{d \alpha^{2}} E G(a, \theta, \alpha)<0$. Hence $\operatorname{sign} \frac{d \alpha}{d \Delta}=\operatorname{sign}\left(\frac{1}{4} \beta e^{-\beta C}\left(\frac{1}{2} \alpha-\beta\right)^{-\frac{3}{2}}\left(\frac{\alpha}{2}\right)^{-\frac{1}{2}}\right)>0$ which again follows from $\alpha-2 \beta>0$.

\section{References}

Adserà, Alícia, Carles Boix, and Mark Payne. 2003. "Are You Being Served? Political Accounatability and Quality of Government." The Journal of Law, Economics \& Organization 19 (2): 445-90.

Alvarez, Michael E., Jose Antonio Cheibub, Fernando Limongi, and Adam Przeworski. 1996. "Classifying Political Regimes." Studies in Comparative International Development 31: 3-36.

Bartels, Larry M. 2008. Unequal Democracy: The Political Economy of the New Guilded Age. Princeton, NJ: Princeton University Press.

Beck, Nathaniel, and Jonathan Katz. 2001. "Throwing the Baby Out with the Bath Water: A Comment on Green, Kim, and Yoon." International Organization 55 (2): 487-95.

Bellver, A., and D. Kaufman. 2005. "Transparenting Transparency: Initial Empirics and Policy Applications." World Bank Policy Research Working Paper. 
Besley, Timothy, and Robin Burgess. 2002. "The Political Economy of Government Responsiveness: Theory and Evidence from India." The Quarterly Journal of Economics 117 (4): 1415-51.

Broz, J. Lawrence. 2002. "Political System Transparency and Monetary Commitment Regimes." International Organization 56 (4): 861-87.

Bueno, de Mesquita, Bruce, Alastair Smith, Randolph M. Siverson, and James D. Morrow. 2003. The Logic of Political Survival. Cambridge, MA: The MIT Press.

Busch, Marc L. 2000. "Democracy, Consultation, and the Paneling of Disputes Under GATT." Journal of Conflict Resolution 44: 425-46.

Carmines, Edward G., and Richard A. Zeller. 1979. Reliability and Validity Assessment. Thousand Oaks, CA: SAGE Publication.

Carter, David B., and Curtis S. Signorino. 2007. "Back to the Future: Modeling Time Dependence in Binary Data." The Society for Political Methodology Working Paper.

Cheibub, Jose Antonio, Jennifer Ghandi, and James Raymond Vreeland. 2010. "Democracy and Dictatorship Revisited." Public Choice 143 (1-2): 67-101.

Crawford, Vincent P., and Joel Sobel. 1982. "Strategic Information Transmission.” Econometrica 50 (6): 1431-51.

Dahl, Robert A. 1971. Polyarchy: Participation and Opposition. New Haven, CT: Yale University Press.

Ferejohn, John. 1986. "Incumbent Performance and Electoral Control.” Public Choice 50: 5-25.

Ferejohn, John. 1999. Accountability and Authority: Toward a Theory of Political Accountability. In Democracy, Accountability and Representation, ed. Bernard Manin, Adam Przeworski, and Susan C. Stokes. Cambridge University Press, 131-53.

Fiorina, Morris P. 1981. Retrospective Voting in American National Elections. New Haven CT: Yale University Press.

Florini, Ann M. 1999. "Does the Invisible Hand Need a Transparency Glove? The Politics of Transparency." Prepared for the Annual World Bank Conference on Development Economics.

Fudenberg, Drew, and Jean Tirole. 1991. Game Theory. Baltimore: The MIT Press.

Green, Donald P., Soo Yeon H. Kim, and David Yoon. 2001. "Dirty Pool." International Organization 55 (2): 441-68.

Heston, Alan, Robert Summers, and Bettina Aten. 2009. Penn World Table Version 6.3. Technical report Center of International Comparisons at the University of Pennsylvania. Center of International Comparisons at the University of Pennsylvania.

Hibbs, Douglas A. 1982. "President Reagan's Mandate from the 1980 Elections." American Politics Research 10: 387-420.

Honaker, James, and Gary King. 2010. "What to Do About Missing Values in Time-Series Cross-Section Data?" American Journal of Political Science 54 (2): 561-81.

Human Rights Watch. 2004. "Some Transparency, No Accountability: The Use of Oil Revenue in Angola and Its Impact on Human Rights.” URL: http://www.hrw.org/reports/2004/ angola0104/accessed March 7, 2011

Islam, Roumeen. 2006. "Does More Transparency Go Along with Better Governance?" Economics and Politics 18 (2): 121-67.

King, Gary, James Honaker, Anne Joseph, and Kenneth Scheve. 2001. "Analyzing Incomplete Political Science Data: An
Alternative Algorithm for Multiple Imputation." American Political Science Review 95 (1): 59-69.

Knack, Stephen, and Philip Keefer. 1995. "Institutions and Economic Performance: Empirical Tests Using Alternative Measures of Institutions." Economics and Politics 73 (3): 207-27.

Kono, Daniel. 2006. "Optimal Obfuscation: Democracy and Trade Policy Transparency." American Political Science Review 100: 369-84

Lewis-Beck, M. 1988. Economics and Elections: The Major Western Democracies. Ann Arbor: University of Michigan Press.

Lewis-Beck, Michael S., and Mary Stegmaier. 2009. "American voter to economic voter: Evolution of an idea." Electoral Studies 28 (4): 625-31.

Mani, Anandi, and Sharun Mukand. 2007. "Democracy, Visibility and Public Good Provision." Journal of Development Economics 83: 506-29.

Mansfield, Edward D., Helen V. Milner, and B. Peter Rosendorff. 2002. "Why Democracies Cooperate More: Electoral Control and International Trade Agreements." International Organization 56 (3): 477-514.

Marshall, Monty G., and Keith Jaggers. 2000. "Polity IV Project: Political Regime Characteristics and Transitions, 1800-1999." www.bsos.umd.edu/cidcm/inscr/polity December.

McMillan, John, and Pablo Zoido. 2004. "How to Subvert Democracy: Montesinos in Peru." Stanford University, Unpublished manuscript.

Mitchell, Ronald B. 1998. "Sources of Transparency: Information Systems in International Regimes." International Studies Quarterly 42 (1): 109-30.

Mosley, Layna. 2003. "Attempting Global Standards: National Governments, International Finance, and the IMF's Data Regime." Review of International Political Economy 10 (2): 331-62.

Przeworski, Adam, Michael E. Alvarez, José Antonio Cheibub, and Fernando Limongi. 2000. Democracy and Development: Political Institutions and Well-Being in the World, 1950-1990. Cambridge: Cambridge University Press.

Przeworski, Adam, Susan C. Stokes, and Bernard Manin. 1999. Democracy, Accountability, and Representation. Cambridge: Cambridge University Press.

Rejali, Darius M. 2007. Torture and Democracy. Princeton, NJ: Princeton University Press.

Rosendorff, B. Peter, and James Raymond Vreeland. 2006. "Democracy and Data Dissemination: The Effect of Political Regime on Transparency." New York University. Unpublished manuscript.

Rosendorff, B. Peter, and John Doces. 2006. "Transparency and Unfair Eviction in Democracies and Autocracies." Swiss Political Science Review 12 (3): 99-112.

Saiegh, Sebastian M. 2011. Ruling by Statute: How Uncertainty and Vote Buying Shape Lawmaking. Cambridge: Cambridge University Press.

Schumpeter, Joseph A. 1942. Capitalism, Socialism, and Democracy. New York: Harper \& Brothers Publishers.

Shapiro, Ian. 2003. The Moral Foundations of Politics. New Haven, CT: Yale University Press.

Stasavage, David. 2003. "Transparency, Democratic Accounatability, and the Economic Consequences of Monetary Institutions." American Journal of Political Science 47 (3): 389-402. 
Stasavage, David. 2004. "Open Door or Closed Door? Transparency in Domestic and International Bargaining." International Organization 58: 667-703.

Stiglitz, J. E. 2002. Transparency in Government. In The Right to Tell, ed. Washington DC: The World Bank.

Vishwanath, T., and D. Kaufmann. 1999. Towards Transparency in Finance and Governance. Washington DC: The World Bank.

Vreeland, James Raymond 2003a. "A Continuous Schumpeterian Conception of Democracy." Prepared for delivery at the annual meeting of the Public Choice Society and Economic Science Association.

Vreeland, James Raymond. 2003b. The IMF and Economic Development. New York: Cambridge University Press.

World Bank. 2010. World Development Indicators on CD-ROM. Washington DC: The World Bank.
James R. Hollyer is Leitner Post-Doctoral Fellow in International and Comparative Political Economy, MacMillan Center, Yale University, P.O. Box 208206, Rosenkranz Hall, 115 Prospect Street New Haven, CT 06520.

B. Peter Rosendorff is Associate Professor of Politics at New York University, 19 West 4th Street, 2nd Floor, New York, NY 10012.

James Raymond Vreeland is Associate Professor of International Relations, Walsh School of Foreign Service and the Department of Government at Georgetown University, Mortara Center for International Studies, 3600 N Street, NW, Washington, DC 20057. 